\title{
SEREBRAL DAN SPINAL DIGITAL SUBTRACTION ANGIOGRAPHY CEREBRAL AND SPINAL DIGITAL SUBTRACTION ANGIOGRAPHY
}

\author{
Tranggono Yudo Utomo* \\ *Staff Pengajar Departemen Neurologi FK UKI Jakarta \\ *Spesialis Saraf RSUD Dr. Dr.Chasbullah Abdulmajid Kota Bekasi \\ E-mail:drtranggonoyudo@gmail.com
}

\begin{abstract}
ABSTRAK
Pengembangan teknologi citra medis terus dilakukan sampai saat ini karena sifatnya yang non-invasif dan memiliki manfaat yang besar dalam membantu klinisi mendiagnosis dan melakukan penatalaksanaan penyakit. Salah satu teknologi citra medis yang digunakan saat ini adalah digital subtraction angiography (DSA), yang berfungsi sebagai alat diagnostik penyakit kardiovaskular. Tulisan ini bertujuan untuk mengkaji berbagai modalitas citra medis vaskular yang ada saat ini termasuk DSA, serta peran pencitra medis DSA dalam menunjang prosedur terapi penyakit serebrovaskular. Metode: Artikel ini berupa telaah literatur yang didapatkan melalui peramban google cendekia dan pubmed dengan kata kunci: "digital substraction angiography, DSA, computed tomography angiography, CTA, neuro intervensi, magnetic resonating angiography, MRA”. Pencitra medis DSA sampai saat ini masih menjadi baku emas untuk mendeteksi penyakit pembuluh darah dan visualisasi diagnostik pada terapi intervensi pada beberapa penyakit vaskular, dengan tingkat resolusi spasial yang tinggi menghasilkan akurasi yang lebih baik dibandingkan dengan MRA dan CTA namun masih memiliki kelemahan dalam hal sifatnya yang invasif, waktu diagnosis dan paparan radiasi. DSA masih lebih unggul dibandingkan modalitas lain untuk kepentingan diagnostik dan sebagai alat penunjang pada terapi endovaskular khususnya stroke, namun beberapa kelemahan DSA akan dapat diatasi dengan perkembangan teknologi dimasa depan. DSA masih relevan digunakan sebagai standar baku dalam diagnosis penyakit vascular.
\end{abstract}

Kata kunci: digital subtraction angiography, DSA, computed tomography angiography , CTA, neuro intervensi, magnetic resonating angiography, MRA.

\begin{abstract}
Medical image technology is continuously developed because of its non-invasive properties and great utilities in helping clinicians diagnose and even manage disease. One such technology is digital subtraction angiography (DSA), which is used as a diagnostic tool for cardiovascular disease. This paper aims to review existing vascular medical imaging modalities including DSA, besides the supportive role of DSA in cerebrovascular disease management. This review was obtained the article through google scholar and pubmed by using keywords: "digital substraction angiography, DSA, computed tomography angiography, CTA, neurointervention, magnetic resonance angiography, $M R A$,". The result showed that DSA is remain a "gold standard" for blood vessel visualisation in both diagnostic and endovascular therapy for several vascular diseases. However, DSA have limitations with regard to its invasiveness, time-consuming for diagnostic screening and radiation DSA is still superior to other modalities for diagnostic purposes and as a supporting tool for endovascular therapy, especially stroke, but some of the weaknesses of DSA will be overcome by future technological development. DSA is still relevant as a standard in the diagnosis of vascular disease.
\end{abstract}

Keywords: digital substraction angiography, DSA, computed tomography angiography, CTA, neuro intervention magnetic resonance angiography, MRA. 


\section{PENDAHULUAN}

Perkembangan teknologi citra digital untuk kesehatan atau citra medis dapat memberikan banyak solusi untuk penegakan diagnosis dan penunjang terapi. Beragam pencitra medis saat ini telah diciptakan dari berbagai modalitas seperti sinar-X, magnetic resonance imaging (MRI), ultrasonografi, radionuklida dan lainnya. Setiap modalitas memiliki kelebihan dan kekurangannya dari sisi kualitas citra atau efek samping yang ditimbulkannya terhadap kesehatan manusia. Saat ini, alat pencitra medis dengan modalitas sinar- $\mathrm{X}$ banyak digunakan dalam ilmu kedokteran, seiring dengan perkembangan teknologi, citra medis yang dihasilkan semakin akurat dan semakin luas aplikasinya. ${ }^{1}$

Sinar-X adalah pancaran gelombang elektromagnetik tinggi dengan panjang gelombang yang rapat, merupakan radiasi pengion yang mampu menembus jaringan tubuh dan menampilkan citra tulang atau jaringan padat lainnya. Namun, sinar-X juga memiliki beberapa efek samping yaitu infertilitas, kanker, bahkan kematian. ${ }^{2,3}$

Beberapa peralatan medis yang dikembangkan dari sinar-X adalah computed tomography scan (CT scan) dan angiografi.
Angiografi merupakan alat diagnosis untuk menampilkan pembuluh darah dalam tubuh dengan menggunakan zat kontras. Peningkatan kualitas citra pembuluh darah pada angiografi dilakukan dengan menggabungkan teknologi perangkat lunak untuk mereduksi bayangan jaringan lain untuk mendapatkan hasil citra pembuluh darah yang lebih fokus dan detail, sehingga mudah dibaca oleh praktisi.

Penggabungan teknologi sinar-X dengan fluoroskopi dan zat kontras serta bantuan perangkat lunak menghasilkan citra medis pembuluh darah yang kontras dan jelas. Perangkat lunak merekayasa citra dengan menggunakan algoritma matematika yang disebut "maskinge untuk mengurangi bayangan latar belakang citra atau bayangan jaringan yang tidak diinginkan. Teknik ini kemudian disebut dengan digital subtraction angiography (DSA). ${ }^{4}$

Sementara itu, pencitra medis sinar-X dengan teknologi tomografi atau CT scan, dibangun dari penggabungan sinar-X dan komputerisasi pergerakan rotasi sensor dan tabung sehingga menghasilkan citra potong lintang atau irisan, untuk menampilkan gambar tomografi berisi informasi lebih rinci tentang organ internal dibandingkan dengan alat sinar-X konvensional. 


\section{TUJUAN}

Artikel ini disusun untuk mengkaji berbagai modalitas citra medis vaskular yang ada saat ini termasuk DSA, serta peran pencitra medis DSA dalam menunjang prosedur terapi penyakit serebrovaskular.

\section{METODE}

Metode yang digunakan adalah telaah literatur dari berbagai jurnal penelitian yang didapatkan melalui mesin pencarian google cendekia dan pubmed dengan kata kunci: “digital substraction angiography, DSA, computed tomography angiography, CTA, neurointervensi, magnetic resonance angiography, MRA," dalam kurun waktu 10 tahun.

\section{PEMBAHASAN}

\section{Digital Substraction Angiografi (DSA)}

Serebral dan spinal digital substraction angiography (DSA) adalah sebuah prosedur invasif yang menggunakan kateter, guide wire, kontras, dengan pencitraan oleh mesin angiografi. Perbedaan yang nyata antara serebral atau spinal angiography dengan serebral atau spinal DSA adalah pada kata substraksinya, dimana pada DSA gambaran tulang kepala akan sangat diminimalisir, sehingga pembuluh darah akan terlihat sangat jelas. Prosedur ini dilakukan untuk menemukan pembuluh darah otak atau spinal yang abnormal (seperti aneurisma, malformasi arteri vena, stenosis) dan menentukan aliran darah dengan kondisi pembuluh darah (seperti vasospasme, vaskulitis, vaskularisasi tumor otak). Dengan melakukan prosedur ini, terapi optimal dapat dilakukan terhadap vaskularisasi otak dan spinal yang abnormal. ${ }^{5}$

Digital substraction angiography dapat dilakukan untuk tujuan diagnostik atau untuk tujuan terapi dalam banyak kasus. Pelatihan operator dan pengalaman dalam teknik kateter, patologi penyakit, dan anatomi vaskular ekstra atau intrakranial bersama dengan evaluasi praprosedural dan manajemen post-prosedural merupakan faktor kunci untuk keberhasilan hasil. Digital substraction angiography memiliki keuntungan untuk melihat ketiga fase aliran darah, yaitu arteri, kapiler, dan vena. ${ }^{6,7}$

\section{Kemampuan dan Akurasi DSA sebagai Pencitra Medis Pembuluh Darah}

Digital subtraction angiography (DSA) memiliki kemampuan dalam menampilkan citra yang terang, jelas dengan resolusi tinggi dibanding dengan pencitra pembuluh darah lainnya, selain itu masih menjadi baku emas dalam mendiagnosis penyakit serebrovaskular. Beberapa pencitra medis yang semakin maju kini dikembangkan untuk menggantikan DSA dengan harapan mengurangi efek samping terhadap pasien. Perkembangan teknologi yang semakin canggih mulai menciptakan 
pencitra medis yang lebih baik dengan tujuan untuk mengurangi perlukaan atau non-invasif, meningkatkan akurasi dan waktu prosedur yang lebih cepat, seperti computed tomography angiography (CTA), magnetic resonance angiography (MRA) dan transcranial doppler (TD), yang dapat dilihat pada tabel 1 .

Tabel 1. Perbedaan pencitra medis pada penyakit serebrovaskular yang ada saat ini.

Tabel 1. Perbedaan pencitra medis pada penyakit serebrovaskular yang ada saat ini

\begin{tabular}{|c|c|c|c|c|}
\hline & DSA & CTA & MRA & $\begin{array}{l}\text { Ultrasound } \\
\text { (Transcranial } \\
\text { Doppler) }\end{array}$ \\
\hline Modalitas & Sinar- $\mathrm{X}$ & Sinar $-\mathrm{X}$ & Medan magnet & Frekuensi suara \\
\hline Zat Kontras & $\mathrm{Ya}$ & $\mathrm{Ya}_{\mathrm{a}}$, sedikit & $\begin{array}{l}\text { Tidak (TOF), } \mathrm{Ya}(\mathrm{CE}- \\
\text { MRA) }\end{array}$ & Tidak \\
\hline $\begin{array}{l}\text { Teknik pengambilan } \\
\text { citra }\end{array}$ & Invasif (kateter) & Invasif & $\begin{array}{l}\text { Non-invasif atau invasif } \\
\text { minim }\end{array}$ & Non-invasif \\
\hline Hasil Citra & coronal plane & $\begin{array}{l}\text { transverse } \\
\text { plane/irisan }\end{array}$ & transverse plane/ irisan & coronal plane \\
\hline Kelebihan & $\begin{array}{l}\text { Resolusi spasial } \\
\text { tinggi, cepat } \\
\text { mengetahui opsi } \\
\text { pengobatan, teknik } \\
\text { baku emas untuk } \\
\text { beberapa indikasi } \\
\text { dan pengambilan } \\
\text { keputusan terapi. }\end{array}$ & $\begin{array}{l}\text { Akurasi hampir } \\
\text { sama dengan } \\
\text { DSA, Kerusakan } \\
\text { hasi citra karena } \\
\text { gerakan kecil, } \\
\text { akusisi data } \\
\text { cepat. }\end{array}$ & $\begin{array}{l}\text { informasi aliran darah } \\
\text { dari aorta sampai ke } \\
\text { pembuluh darah kepala, } \\
\text { TOF MRA tidak } \\
\text { menggunakan zat } \\
\text { kontras } \\
\text { Tidak ada radiasi } \\
\text { pengion }\end{array}$ & $\begin{array}{l}\text { Lebih murah, } \\
\text { portabel, } \\
\text { banyak tersedia, } \\
\text { dapat } \\
\text { memonitor } \\
\text { informasi aliran } \\
\text { darah saat itu. } \\
\text { Tidak ada } \\
\text { radiasi pengion }\end{array}$ \\
\hline Kekurangan & $\begin{array}{l}\text { Sangat bergantung } \\
\text { zat kontras, terpapar } \\
\text { radiasi }\end{array}$ & $\begin{array}{l}\text { Sangat } \\
\text { bergantung zat } \\
\text { kontras, terpapar } \\
\text { radiasi }\end{array}$ & $\begin{array}{l}\text { Feasibility terbatas } \\
\text { untul pasien akut, } \\
\text { kontraindikasi pada } \\
\text { pasien dengan implan, } \\
\text { gerakan pasien } \\
\text { menimbullkan artefak, } \\
\text { akurasi rendah }\end{array}$ & $\begin{array}{l}\text { Sangat } \\
\text { bergantung pada } \\
\text { pengalaman dan } \\
\text { keahlian } \\
\text { operator, serta } \\
\text { pada teknik } \\
\text { menghilangkan } \\
\text { citra tulang } \\
\text { karena tanpa } \\
\text { kontras }\end{array}$ \\
\hline Indikasi klinis & 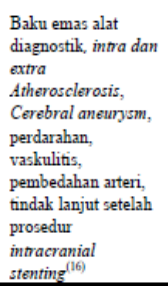 & $\begin{array}{l}\text { Acute cerebral } \\
\text { ischemia, imtra- } \\
\text { dan } \\
\text { extracreanial } \\
\text { atherosclerosis, } \\
\text { cerebral } \\
\text { aneurysm/AVM } \\
\text { /cavemomas, } \\
\text { perdarahan. }\end{array}$ & $\begin{array}{l}\text { Penyakit } \\
\text { Atherosclerosis intra- } \\
\text { \& extracranial, } \\
\text { cerebral } \\
\text { aneurysm/arteriovenous } \\
\text { malformations, } \\
\text { pembedahan arteri, } \\
\text { perdarahan }{ }^{(16)}\end{array}$ & $\begin{array}{l}\text { Acute cerebral } \\
\text { ischemia, } \\
\text { intracranial } \\
\text { atherosclerotic, } \\
\text { vasomotor } \\
\text { reactivity, } \\
\text { emboli serebral }\end{array}$ \\
\hline
\end{tabular}

Akurasi teknologi pencitra medis pembuluh darah DSA pada indikasi klinis penyakit serebrovaskular, telah dibahas dalam banyak penelitian. Saat ini DSA masih memiliki kemampuan deteksi penyakit vaskular yang lebih baik dibanding dengan modalitas lainnya seperti MRA, CTA, hal ini dapat dilihat pada tabel 2.

Tabel 2. Perbandingan akurasi diagnostic antara DSA, CTA dan MRA.

Tabel 2. Perbandingan akurasi diagnostik antara DSA, CTA dan MRA

\begin{tabular}{|c|c|c|c|c|}
\hline Peneliti & DSA. & CTA & MRA & Outcome \\
\hline $\begin{array}{lrl}\text { Richard } & \text { E. } & \text { AHA } \\
\text { Latchaw, } & \text { ddkk } & \text { Scientific } \\
(2009)(13) & & \text { Statement }\end{array}$ & $\begin{array}{l}\text { - Invasif } \\
\text { - Standar balku } \\
\text { yang } \\
\text { memiliki } \\
\text { sensitivitas } \\
\text { dan } \\
\text { spesifisitas } \\
\text { yang sama } \\
\text { bahkan } \\
\text { melebihi } \\
\text { teknil non } \\
\text { invasif lain. }\end{array}$ & $\begin{array}{l}\text { - Non-invasif } \\
\text { - Sensitivitas } \\
>80 \% \text { dan } \\
\text { Spesifisitas } \\
90 \% \text { untulk } \\
\text { mendeteksi } \\
\text { signifikan lesi } \\
\text { dan senstivitas } \\
\text { yang sama } \\
\text { untuk } \\
\text { mendiagnosis } \\
\text { Severe carotid } \\
\text { stenosis } \\
\text { dibanding } \\
\text { DSA }\end{array}$ & $\begin{array}{l}\text { - Non-invasif } \\
\text { - Sensitivitas } \\
86-97 \% \\
\text { dan } \\
\text { spesifisitas } \\
62-91 \% \\
\text { untuk } \\
\text { mendeteksi } \\
\text { stenosis } \\
\text { karotis }\end{array}$ & $\begin{array}{l}\text { DSA tetap menjadi } \\
\text { teknik yang paling } \\
\text { optimal untuk } \\
\text { pencitraan pembuluh } \\
\text { darah kepala. } \\
\text { Modalitas non- invasif } \\
\text { umunya memiliki } \\
\text { kesamaan dalam } \\
\text { pembacan citra medis } \\
\text { dengan DSA, walau } \\
\text { masing-masing teknik } \\
\text { memiliki kelebihan } \\
\text { tersendiri }\end{array}$ \\
\hline $\begin{array}{l}\text { M. Hanley, dkk In-vitro } \\
(2008)(17)\end{array}$ & $\begin{array}{l}\text { Perhitungan } \\
\text { dalam } 7 \text { model } \\
\text { rata-rata absolut } \\
\text { variance: } \\
14.3(+13.1) \\
\text { Rata-rata true } \\
\text { variance: } \\
(\mathrm{p}=0,030)=-1.9\end{array}$ & $\begin{array}{l}\text { Perhitungan } \\
\text { dalam } 7 \text { model } \\
\text { rata-rata absolut } \\
\text { variance: } \\
16.8(+19.9) \\
\text { Rata-rata true } \\
\text { variance: } \\
(\mathrm{p}=0,030)=16.1\end{array}$ & $\begin{array}{l}\text { Perhitungan } \\
\text { dalam } 7 \text { model } \\
\text { rata-rata } \\
\text { absolut } \\
\text { variance: } \\
18.6 \quad(+18.0) \\
\text { Rata-rata true } \\
\text { variance: } \\
(\mathrm{p}=0,030)=\text { - } \\
15.9\end{array}$ & $\begin{array}{l}\text { Rata-rata citra volume } \\
\text { model dari } 3 \\
\text { modalitas DSA, CTA } \\
\text { dan MRA adalah Citra } \\
\text { CTA lebih besar dari } \\
\text { ukuran volume acuan, } \\
\text { citra MRA kurang dari } \\
\text { volume acuan, dan } \\
\text { DSA menghasilkan } \\
\text { citra yang kurang dan } \\
\text { lebih sama. }\end{array}$ \\
\hline $\begin{array}{l}\text { Jason C. Smith, In-vitro } \\
\text { dkk (2012)(18) }\end{array}$ & $\begin{array}{l}\text { Keseluruhan } \\
\text { nilai stenosis: } \\
67 \% \cdot 100 \%\end{array}$ & $49 \%-100 \%$ & $42 \%-100 \%$ & $\begin{array}{l}\text { CTA dan MRA } \\
\text { memiliki nilai lebih } \\
\text { rendah secara } \\
\text { bermakna dibanding } \\
\text { AAR } \\
\text { (masing-masing, } p= \\
0.001 \text { dan } p=0.0009 \text { ), } \\
\text { sedangkan tidak di } \\
\text { temukan perbedaan } \\
\text { bermakna antara nilai }\end{array}$ \\
\hline
\end{tabular}

Digital subtraction angiography menjadi

pencitra medis yang popular karena memiliki tingkat resolusi spatiotemporal yang tinggi, berarti citra dapat terlihat lebih detail dibanding dengan teknik lainnya seperti magnetic resonance imaging (MRI) atau custom tissue imaging (CTI). Ketidaknormalan pada pembuluh darah seperti penyempitan, penyumbatan atau cacat pada pembuluh darah 
dapat dilihat secara jelas pada DSA. Digital subtraction angiography memang masih invasif namun tergolong minim, biaya terjangkau, risiko relatif kecil, dan juga pelaksanaan waktu pengoperasian yang relatif cepat. Penelitian kohort yang dilakukan Wang dkk, lebih merekomendasikan CT untuk memperoleh data pada pengambilan keputusan saat kegawatdaruratan, salah satunya karena lebih efisien waktu, dan dengan adanya prediksi bahwa DSA akan digantikan oleh CTA untuk intervensi neurovaskular nantinya, namun DSA sampai saat ini masih menjadi baku emasnya. ${ }^{8,9}$

Aplikasi diagnosis DSA dapat digunakan untuk memvisualisasikan struktur dari pembuluh darah intrakranial, kelainan pembuluh darah seperti malformasi arteriovenosa, aneurisma, stenosis karotis, serta gradasi penyakit Moyamoya dan aliran kolateral pada oklusi arteri serebral akut. ${ }^{10-13}$

Penggunaan DSA pada pendeteksian dengan metode in vitro memiliki sensitivitas yang lebih tinggi dari CTA dan MRA. Pada dua penelitian klinis dengan metode RCT yang mengulas sensitivitas dan spesifisitas citra masing-masing alat diketahui bahwa CTA memiliki hasil deteksi yang lebih baik dibanding DSA. Hal ini hampir sama dengan kajian yang dilakukan oleh Sanelli, dkk, dengan melakukan kajian berbasis bukti untuk mencari penanganan terbaik pada pasien stroke iskemik.

Hasil kajian menunjukan bahwa CT menjadi alat deteksi pertama untuk pasien stroke iskemik dengan akurasi yang sama dengan MRA, walau MRA masih lebih baik dalam mendeteksi stroke iskemik pada 24 jam pertama. $^{14}$

\section{Manfaat Pemeriksaan DSA. ${ }^{5}$}

1. Pemeriksaan DSA merupakan pemeriksaan "gold standard" untuk mengetahui adanya aneurisma yang menyebabkan perdarahan subarakhnoid spontan, apakah sudah terjadi vasospasme ataupun malformasi pembuluh darah ekstra dan intrakranial.

2. Pemeriksaan DSA memberikan efektivitas dan keoptimalan dalam hal waktu bila kita ingin melakukan sekaligus pemeriksaan pada keadaan stroke iskemik (setelah CT scan kepala) dan sekaligus tindakan terapi trombolisis.

3. Dengan pemeriksaan DSA kita dapat mengetahui hasil yang lebih akurat bila kita dihadapkan dengan suatu keadaan stenosis ataupun oklusi dibanding dengan pemeriksaan lainnya.

4. Dengan DSA kita bisa melihat adakah koletaral-kolateral dari cabang-cabang 
pembuluh darah distal bila kita ingin melakukan oklusi pada salah satu cabang pembuluh darah tertentu, agar suplai aliran darah ke daerah yang akan kita oklusi tersebut dapat terjamin.

5. Pada kasus pasca trauma kepala (khususnya sedang dan berat), DSA dapat digunakan untuk menyingkirkan adanya pseudo-aneurisma yang seringkali timbul pasca trauma kepala khususnya pada pasien-pasien yang seringkali mengeluh nyeri kepala yang tidak kunjung hilang (membaik setelah minum obat namun kambuh lagi bila pengaruh obat habis) hingga beberapa bulan setelah kejadian.

6. DSA dapat menunjukan secara lebih jelas dan terperinci, pembuluh darah mana yang menjadi "feeder" suatu tumor intrakranial berikut peta perjalanan ke tumor tersebut, sehingga kita bisa menyusun strategi bila kita ingin melakukan embolisasi guna membantu sejawat bedah saraf sebelum mereka melakukan reseksi.

Tabel karakteristik mengenai manfaat dalam penggunaan DSA dapat dilihat pada tabel berikut.

Tabel 1. Karakteristik Manfaat Penggunaan DSA

\begin{tabular}{llllr}
\hline \multicolumn{1}{c}{ Referensi } & \multicolumn{2}{c}{ Metode } & \multicolumn{2}{c}{ Hasil } \\
\hline Putranto & Studi & deskriptif & IAHF & memiliki \\
$\mathrm{dkk}^{7}$ & pada & data & tingkat & komplikasi \\
& radiologi & & akut yang & rendah. \\
& intervensi & yang & Sebagian & besar \\
\hline
\end{tabular}

\begin{tabular}{|c|c|c|}
\hline & menjalani IAHF & $\begin{array}{l}\text { komplikasi } \\
\text { berhubungan } \\
\text { dengan control } \\
\text { hemostasis local, } \\
\text { dan adanya squeal } \\
\text { berat } \\
\text { ditemukan. }\end{array}$ \\
\hline Bashir $\mathrm{dkk}^{6}$ & $\begin{array}{l}\text { Studi retrospektif } \\
\text { mengenai } \\
\text { demografis } \\
\text { pasien, prosedur } \\
\text { teknis, dan } \\
\text { komplikasi } \\
\text { dengan mencatat } \\
\text { komplikasi } \\
\text { neurologi dan } \\
\text { sistemik dalam } \\
24 \text { jam }\end{array}$ & $\begin{array}{l}\text { Diagnostic } \\
\text { cerebral/spinal } \\
\text { digital subtraction } \\
\text { angiography } \\
\text { terbukti aman di } \\
\text { Pakistan, dengan } \\
\text { tingkat komplikasi } \\
\text { yang sama dengan } \\
\text { yang dilaporkan } \\
\text { pada negara } \\
\text { berkembang. }\end{array}$ \\
\hline $\begin{array}{l}\text { Scalzo dkk } \\
9\end{array}$ & $\begin{array}{l}\text { Studi } \\
\text { ekperimental } \\
\text { pada pasien strok } \\
\text { akut tipe iskemi } \\
\text { dengan tindakan } \\
\text { DSA dan } \\
\text { dianalisis secara } \\
\text { kuantitatif dan } \\
\text { visualisasi aliran } \\
\text { darah }\end{array}$ & $\begin{array}{l}\text { Analisis kuantitatif } \\
\text { dan visualisasi dari } \\
\text { parameter aliran } \\
\text { darah } \\
\text { dialkukan dapat } \\
\text { menggunakan DSA, } \\
\text { berdasarkan } \\
\text { deconvolution dari } \\
\text { kurva waktu - } \\
\text { densitas. }\end{array}$ \\
\hline $\begin{array}{l}\text { Hanley dkk } \\
10\end{array}$ & $\begin{array}{l}\text { Studi } \\
\text { experimental } \\
\text { menggunakan } \\
\text { silicon model } \\
\text { aneurisma untuk } \\
\text { menghitung } \\
\text { volum cerebral, } \\
\text { perbandingan } \\
\text { DSA, CTA dan } \\
\text { MRA }\end{array}$ & $\begin{array}{l}\text { CTA memiliki hasil } \\
\text { lebih tinggi dari } \\
\text { estimasi, } \\
\text { dibawah estimasi, } \\
\text { sedangkan DSA } \\
\text { keduanya baik } \\
\text { dibawah maupun } \\
\text { diatas estimasi }\end{array}$ \\
\hline $\begin{array}{l}\text { Jansen } \mathrm{dkk} \\
12\end{array}$ & $\begin{array}{lr}\text { RCT dalam MR } \\
\text { clean dan oklusi } \\
\text { middle cerebral } \\
\text { artery r dan } \\
\text { dengan keduanya } \\
\text { baik gambaran } \\
\text { CTA r dan } \\
\text { penilaian DSA. }\end{array}$ & $\begin{array}{lr}\text { CTA secara } \\
\text { signifikan } \\
\text { berhubungan } \\
\text { dengan mRS } \\
\text { hari ke } \\
\text { sedangkan } \\
\text { tidak. }\end{array}$ \\
\hline $\begin{array}{l}\text { Putranto } \\
\mathrm{dkk}^{15}\end{array}$ & $\begin{array}{l}\text { Studi } \\
\text { ekperimental pre } \\
\text { dan post dengan } \\
\text { RCT dan diukur } \\
\text { MMT (Manual } \\
\text { Muscle testing) } \\
\text { melalui metode } \\
\text { Intra arterial } \\
\text { heparin flushing } \\
\text { pada pasien strok } \\
\text { iskemik kronik }\end{array}$ & $\begin{array}{lr}\text { Intra } & \text { Arterial } \\
\text { Heparin } & \text { Flushing } \\
\text { secara signifikan } \\
\text { memberikan efek } \\
\text { pada pasien stroke } \\
\text { kronik dengan } \\
\text { menurunkan } \\
\text { kekuatan } \\
\text { dimana otot, } \\
\text { menunjukkan nilai } \\
\text { yang signifikan } \\
\text { pada MMT-MRC }\end{array}$ \\
\hline
\end{tabular}




\begin{tabular}{llll}
\hline & \multicolumn{3}{l}{ score. } \\
\hline Choo dkk $^{16}$ & Studi retrospektif & Penggunan dual \\
& pada rekam & anti-platelet (aspirin \\
& medis pasien yg & dan cilostazol) 7 \\
& menjalani DSA & hari sebelum DSA \\
dengan & & dapat ereduksi \\
premedikasi & resiko cerebral \\
aspirin & dan & DSA-induced TEC \\
cilostazol & & & \\
\hline
\end{tabular}

\section{Indikasi Pemeriksaan DSA}

Pemeriksaan DSA dapat dilakukan apabila terdapat adanya malformasi di otak atau medula spinalis berdasarkan klinis atau pencitraan MRI atau MRA, adanya aneurisma pada kasus kasus perdarahan subaraknoid, stroke iskemik pertama dengan faktor risiko mayor lebih dari 2 atau 2 faktor risiko mayor dan 1 faktor risiko minor, stroke iskemik berulang, stroke perdarahan dengan topis di daerah kortikal, adanya fistula karotis kavernosus berdasarkan klinis dan anamnesa, adanya stenosis pembuluh darah leher otak berdasarkan pemeriksaan non invasif, tumor kaya pembuluh darah di daerah leher dan otak (meningioma, hemangioma, angiofibroma) berdasarkan klinis atau pencitraan terkait sebelumnya, diagnostik kematian. ${ }^{5}$

Indikasi DSA secara luas dibagi menjadi penyakit serebral dan spinal. Indikasi serebral selanjutnya diklasifikasikan berdasarkan patologi intrakranial dan ekstrakranial, yang dapat dilihat pada tabel $2{ }^{6}$

Tabel 2. Indikasi neuroangiografi

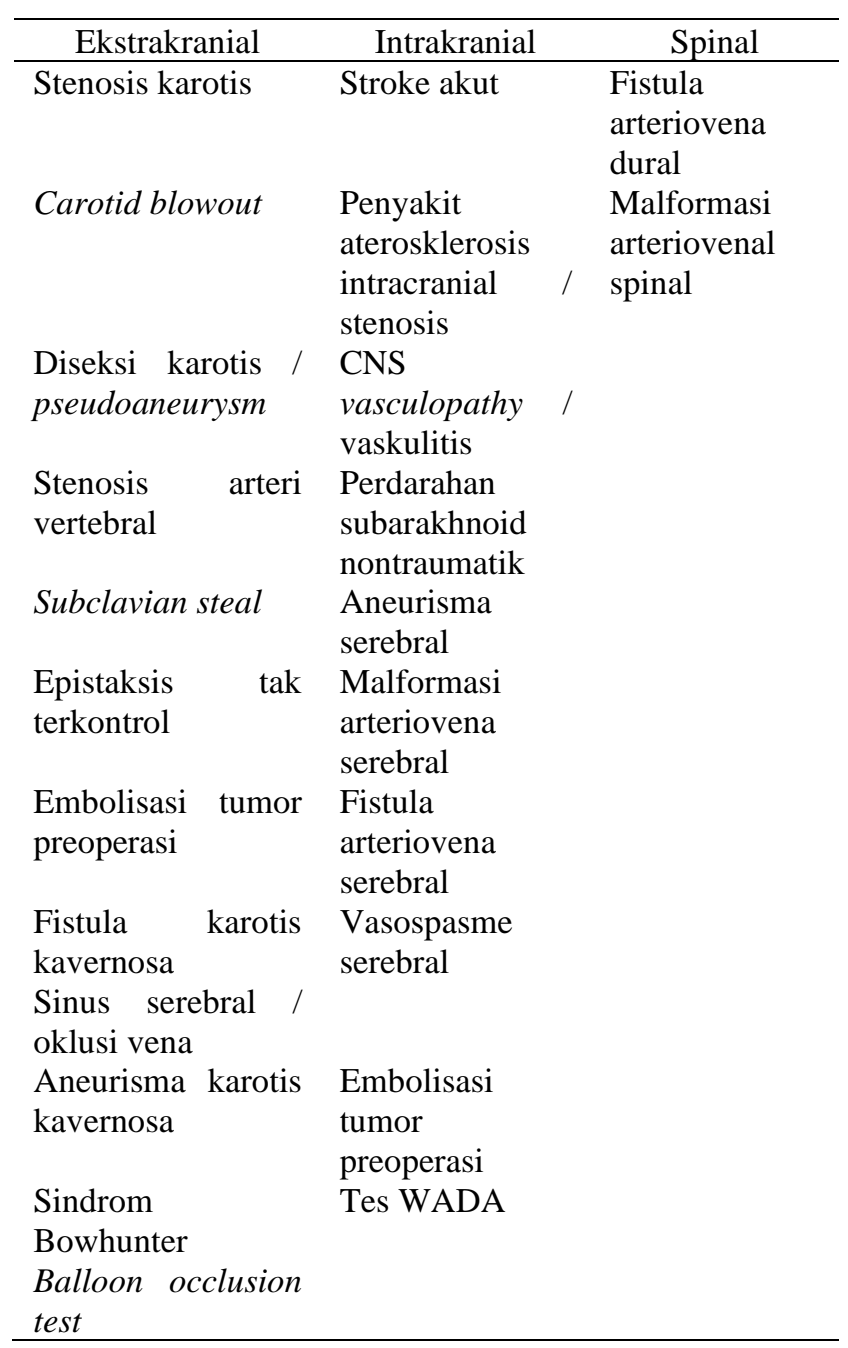

\section{Protokol DSA}

Prosedur serebral dan spinal DSA relatif aman bila dilakukan oleh neurointervensionis, baik dari aspek komplikasi neurologi dan nonneurologi, dan dari jumlah kematian. Rerata komplikasi neurologi jauh di bawah batas yang direkomendasi oleh quality improvement dan safe practice guidelines. ${ }^{5}$

Dilakukan observasi terhadap tanda vital dan tanda neurologis pasien sebelum dan sesudah prosedur. Pemeriksaan laboratorium darah yang dilakukan adalah hemoglobin, erithrosit, 
leukosit, trombosit, SGOT/SGPT, ureum dan kreatinin, HBSAg. Pasien dianjurkan tidak memakan makanan padat selama 6 jam sebelum prosedur. Pada semua pasien, jalur intravena telah dipasang lebih dahulu sebelum angiografi. Selama prosedur dilakukan pemantauan terhadap elektrokardiografi (EKG), saturasi oksigen, dan tanda-tanda vital (tekanan darah, frekuensi nadi dan frekuensi pernapasan). Apabila dalam pemeriksaan laboratorium didapatkan hemoglobin <10 gr/dL, SGOT dan SGPT yang meningkat lebih dari 2x nilai normal dan kadar kreatinin darah $>2 \mathrm{mg} / \mathrm{dL}$ maka prosedur pemeriksaan serebral DSA dibatalkan. ${ }^{5}$

Penusukan arteri femoralis sisi kanan dilakukan pada semua prosedur dengan menggunakan jarum puncture, kemudian dimasukkan selubung femoral (femoral sheath) berukuran 4F untuk anak. Femoral sheath ukuran $5 \mathrm{~F}$ digunakan pada remaja yang sudah memiliki postur tubuh seperti orang dewasa. Flushing cairan digunakan secukupnya 1000 cc larutan isotonis $\mathrm{NaCl}$ 0,9\% ditambah 5000 IU heparin. Selain itu diawal prosedur digunakan juga heparin dengan dosis 25-50 IU / kg.

Untuk keperluan diagnostik, digunakan sebuah guide wire (kawat pemandu) dan diagnostic catheter head hunter tipe biasa, dengan lebar 0,035 inchi. Melalui kateter, cairan isotonik dengan heparin dialirkan perlahan untuk mencegah pengentalan darah dalam kateter. Kontras non-ionik, larut dalam air, iso osmolar dan beriodinasi dicampur dengan cairan isotonis yang sudah dipersiapkan pada rasio 2:1 digunakan. Kontras disuntikkan secara manual sebanyak 4-6 ml dengan kecepatan 2-3 $\mathrm{ml} /$ detik pada arteri karotis utama dan arteri karotis internal, $3 \mathrm{ml}$ dengan kecepatan 3 $\mathrm{ml} /$ detik pada arteri vertebral dan 3-4 ml dengan 2-4ml/detik pada arteri subklavia. Dosis total maksimal pemberian kontras murni pada prosedur adalah $2-3 \mathrm{~mL} / \mathrm{kgBB}$. Saat prosedur selesai, selubung femoral ditarik dan pada pangkal paha pasien, dilakukan kompresi selama 15-20 menit. Setelah prosedur selesai, dilakukan pemeriksaan tanda vital dan pemeriksaan neurologi. Pasien dipantau oleh perawat di area pemulihan selama istirahat total setidaknya selama 4 jam. Setelah kondisi pasien stabil, pasien dipindahkan ke ruang pemulihan selama 6-8 jam. ${ }^{5,6}$

\section{Kontraindikasi dan Komplikasi DSA}

Meskipun tidak ada kontraindikasi absolut untuk prosedur angiografi, beberapa kontraindikasi relatif dipertimbangkan. Hal ini termasuk insufisiensi ginjal, riwayat reaksi anafilaksis yang parah terhadap media kontras (bahkan dengan terapi awal steroid) atau koagulopati dengan peningkatan risiko delayed hemostasis. ${ }^{6}$ 
Hematoma dapat terjadi di tempat punctur, namun bila timbul tidak perlu terlalu dikhawatirkan, karena dengan penatalaksanaan antibiotik spektrum luas dan kortikosteroid, biasanya mereda dalam 5-10 hari. $^{5}$

Prosedur endovaskular seperti DSA akan berisiko tanpa penghambatan kaskade koagulasi. Permukaan sintetis dari kateter dan wire bersifat trombogenik. Selain itu, kerusakan jaringan akibat pungsi pembuluh darah, jahitan, dan angioplasti mengekspos faktor jaringan yang berperan sebagai pemicu koagulasi. Penggunaan heparin selama prosedur intervensi, baik sebagai bolus atau diencerkan dengan saline untuk membilas kateter telah dipraktikkan, dan sifat antitrombotik heparin memegang peran yang sangat diperlukan untuk sebagian besar prosedur intervensi. ${ }^{15}$

Heparin tidak hanya sebagai antikoagulan tetapi juga fibrinolitik karena dapat meningkatkan konversi plasminogen menjadi plasmin dengan menstimulasi aktivator plasminogen. Karena efeknya, heparin memiliki efek samping yang umum termasuk perdarahan, hematoma, dan waktu kompresi yang lama untuk menghentikan perdarahan. ${ }^{7}$

Diantara berbagai komplikasi DSA serebral termasuk mual, muntah, transien hipotensi, anafilaksis, dan groin hematoma, terdapat juga komplikasi neurologis sekunder akibat tromboemboli. Tromboemboli adalah komplikasi paling signifikan dari DSA serebral, yang terjadi akibat pembentukan trombus dalam kateter, dalam plak trombotik intravaskular yang sudah ada sebelumnya, atau diseksi mikro yang diinduksi oleh perangkat. Kebanyakan tromboemboli terjadi dalam 48 jam pertama pasca intervensi. Faktor risiko stroke iskemik setelah DSA serebral meliputi hipertensi, diabetes mellitus, dislipidemia, gangguan jantung seperti gagal jantung atau aritmia, riwayat merokok, penyakit ginjal kronis, jumlah kateter yang digunakan, jenis kateter yang digunakan, dan volume zat kontras yang digunakan. Penelitian yang dilakukan oleh Choo dkk, mengatakan bahwa penggunaan agen antiplatelet ganda (aspirin dan cilostazol) selama seminggu sebelum prosedur dapat mengurangi risiko komplikasi yang diinduksi DSA serebral. Terapi antiplatelet praprosedural dapat secara efektif mengurangi tromboemboli yang diinduksi DSA serebral. ${ }^{16}$

Dari sekian keunggulan DSA dari pencitra lainnya, DSA memiliki kelemahan yaitu adanya paparan radiasi ke pasien ataupun operator, teknik pencitraan dengan metode invasif atau perlukaan menggunakan kateter melalui vena dan waktu diagnosis DSA lebih lama dibandingkan waktu diagnosis dengan CTA. $^{17}$ 


\section{KESIMPULAN}

Pada studi literatur ini disimpulkan bahwa DSA masih relevan digunakan sebagai standar baku dalam diagnosis penyakit vaskular, namun saat diagnosis awal pada stroke di ketahui bahwa diagnosis menggunakan CT lebih murah dan cepat dibanding dengan DSA. Penggunaan DSA sebagi alat penunjang citra medis pada terapi endovaskular khususnya stroke masih menjadi baku emas karena memiliki akurasi yang tinggi dan biaya yang relatif lebih rendah dibanding dengan MRA atau CTA, dan terapi endovaskular memberikan harapan kesembuhan yang lebih cepat dari prosedur standard lainnya. Kekurangan DSA adalah teknik yang invasif, waktu prosedur yang relatif lama, kemungkinan adanya alergi zat kontras serta adanya risiko paparan radiasi pada pasien dan operator. Teknologi yang semakin berkembang pada CTA dan MRA dapat menggantikan peran DSA dimasa depan, dengan deteksi penyakit kardiovaskular yang lebih cepat, non-invasif dan lebih unggul terkait perlindungan terhadap paparan radiasi.

\section{SARAN}

Studi lanjut berbasis klinis perlu dilakukan untuk menilai penggunaan modalitas DSA secara lebih objektif, dengan fokus studi multisenter untuk mendapatkan persebaran data yang lebih baik.

\section{UCAPAN TERIMA KASIH}

Penulis mengucapkan rasa terima kasih kepada dr. Fritz Sumantri Usman, Sp.S (K), FiNS, FINA, selaku guru dan pembimbing yang telah memberikan ilmu dan pengetahuan selama fellow di RS. Fatmawati Jakarta.

\section{DAFTAR PUSTAKA}

1. Laviña B. Brain vascular imaging techniques. Int J Mol Sci. 2016;18(1).

2. Fauziyah A, Dwijananti P. Pengaruh radiasi sinar $X$ terhadap motilitas sperma pada tikus mencit ( Mus muculus ). J Pendidik Fis Indones (Indonesian J Phys Educ. 2013;9(1):93-8.

3. Dong Ik Kim M. Preface : How dangerous are X-ray studies that we undertake every day? J Korean Med Sci. 2016;31:10-1.

4. Moore WS. Vascular and Endovascular Surgery: A Comprehensive Review. Vol. 23, Bollettino della Societa italiana di biologia sperimentale. 2012. 1112 p.

5. Sarisanti R, Usman FS. Cerebral and spinal DSA; when and how. Available from : https://www.perdossi.org/wpcontent/uploads/2016/04/NEVI-001-201605-Cerebral-and-Spinal-DSA-When-andHow.pdf.

6. Bashir Q, Ishfaq A, Baig AA. Safety of diagnostic cerebral and spinal digital substraction angiography in a developing country: a single-center experience. Intervent Neurol. 2018;7:99-109.

7. Putranto TA, Astoro NW, Rachmad B, Setiawan E, Pramono A, Djuwita, et al. The safety of modified digital substaction angiography in RSPAD Gatot Soebroto: a comprehensive outlook. Bali Med J. 2020;9(1):1-5.

8. Wang X, Arima $\mathrm{H}$, Yang J, Zhang S, Wu G, Woodward M. Mannitol and Outcome in Intracerebral Hemorrhage. Propensity Score and Multivariable Intensive Blood Pressure Reduction in Acute Cerebral 
Hemorrhage Trial 2 Results. Stroke. 2015;46:2762-7.

9. Scalzo F, Liebeskind DS. Perfusion Angiography in Acute Ischemic Stroke. Comput Math Methods Med. 2016;2016.

10. Hanley M, Zenzen WJ, Brown MD, Gaughen JR, Evans AJ. Comparing the Accuracy of Digital Subtraction Angiography, CT Angiographyand MR Angiography at Estimating the Volume of Cerebral Aneurysms. Interv Neuroradiol. 2008;14(2):173-7.

11. Smith JC, Watkins GE, Smith DC, Palmer EW, Abou-Zamzam AM, Zhao CX, et al. Accuracy of digital subtraction angiography, computed tomography angiography, and magnetic resonance angiography in grading of carotid artery stenosis in comparison with actual measurement in an in vitro model. Ann Vasc Surg [Internet]. 2012;26(3):338-43.

12. Jansen IGH, Berkhemer OA, Yoo AJ, Vos JA, Nijeholt GJL, Sprengers MES, et al. Comparison of CTA-And DSA-based collateral flow assessment in patients with anterior circulation stroke. Am J Neuroradiol. 2016;37(11).

13. Barr JD. Cerebral Angiography in the assessment of acute cerebral ischemia: 18 Jurnal Biotek Medisiana Indonesia Vol.7 No.1 2018; 9-18 guidelines and recommendations. J Vasc Interv Radiol [Internet]. 2004;15(1):S57-66.

14. Sanelli PC, Sykes JB, Ford AL, Lee J-M, Vo KD, Hallam DK. Imaging and treatment of patients with acute stroke: An evidence-based review. Am J Neuroradiol [Internet]. 2014;35(6):1045-51.

15. Putranto T.A., Yusuf I., Murtala B., Wijaya A. Intra Arterial Heparin Flushing Increases Cereberal Blood Flow in Chronic Ischemic Stroke Patients. Indones Biomed J. 2016;8(2):119.

16. Choo YH, Jung YJ, Chang CH, Kim JH. Efficacy of dual antiplatelet therapy as premedication before diagnostic cerebral digital substraction angiography. J
Cerebrovasc Endovasc Neurosurg. 2019;21(3):131-7.

17. Sun G, Ding J, Lu Y, Li M, Li L, Li G ying, et al. Comparison of standard- and low-tube voltage 320-detector row volume CT Angiography in detection of intracranial aneurysms with digital subtraction angiography as gold standard. Acad Radiol. 2012;19(3):281-8. 